\title{
Genomic of resistance for Fusarium circinatum in Pinus radiata
}

\author{
Rodrigo Hasbun ${ }^{1 *}$, Priscila Moraga ${ }^{2}$, Pamela Wachtendorff', Carolina Iturra ${ }^{3}$, Angela Carrasco $^{2}$, Claudio Balocchi $^{4}$, \\ Sofía Valenzuela ${ }^{2}$ \\ From IUFRO Tree Biotechnology Conference 2011: From Genomes to Integration and Delivery \\ Arraial d'Ajuda, Bahia, Brazil. 26 June - 2 July 2011
}

The pitch canker fungus Fusarium circinatum was first associated with mortality of $P$. radiata in California during the 1980s. Since then it has been dispersed to several countries of the Northern hemisphere together with South Africa and Chile in the southern hemisphere. In Chile the disease caused mortality of seedlings in $P$. radiata at nursery, and in South Africa the pathogen has already completed its life cycle in plantations. This situation could be replicated in Chile, in the short-term, becoming then a major problem due to that most of the commercial plantations correspond to radiata pine. Research and breeding programs to ensure the availability of resistant trees are essential.

Controlled inoculation trials using different pine species have shown the high susceptibility of $P$. radiata[1]. Different families of radiata pine in Australia, New Zealand and Chile have been screened, showing a considerable genetic variation for lesion length and a high heritability depending on the population, suggesting that selection for resistance should result in useful genetic gains [2]. Based on the above findings a molecular approach of pitch canker resistance in $P$. radiata was carried out. This study focuses on the discovery of genome regions associated with resistance and the genes involved in the response mechanism(s), to develop genomic tools for breeding resistance.

The resistance to $F$. circinatum was investigated using a Quantitative Trait Locus (QTL) mapping strategy in a full-sib family of $P$. radiata. This mapping project used a double pseudo testcross approach to map each of the parents with dominant markers. Microsatellite (SSR) and Amplified Fragment Length Polymorphism (AFLP) markers were used to genotype the two parents (XO and $\mathrm{XP}$ ) and the progeny (86 clones). Both parental maps were joined using the co-dominant SSR and AFLP markers to obtain a saturated genetic map. For each clone (approximately 8 ramets/clone) inoculations were carried out at Bioforest S.A. and lesion lengths were measured 90 days later. Phenotypic data together with genetic map allowed identified and positioned QTLs that control part of the pitch canker resistance in the progeny. Using Windows QTL Cartographer three QTLs were detected for the trait of interest for both parents.

\section{Author details}

${ }^{1}$ Genomica Forestal S.A. Edificio Centro de Biotecnologia s/n. Universidad de Concepción. Concepción, Chile. ${ }^{2}$ Facultad de Ciencias Forestales. Universidad de Concepción. Concepción, Chile. ${ }^{3}$ Genomica Forestal S.A. Edificio Centro de Biotecnologia s/n. Universidad de Concepción. Concepción, Chile.

${ }^{4}$ Bioforest S.A. Concepción, Chile.

Published: 13 September 2011

\section{References}

1. Hodge G, Dvorak W: Differential responses of Central American and Mexican pine species and Pinus radiata to infection by the pitch canker fungus. New Forest 2000, 19:241-258.

2. Matheson A, Devey M, Gordon T, Werner W, Vogler D, Balocchi C, Carson M: Heritability of response to inoculation by pine pitch canker of seedlings of radiata pine. Australian Forestry Journal 2006, 70:101-106.

doi:10.1186/1753-6561-5-S7-P28

Cite this article as: Hasbun et al:: Genomic of resistance for Fusarium circinatum in Pinus radiata. BMC Proceedings 2011 5(Suppl 7):P28.

\footnotetext{
* Correspondence: rodrigohasbun@udec.cl

${ }^{1}$ Genomica Forestal S.A. Edificio Centro de Biotecnologia s/n. Universidad de Concepción. Concepción, Chile

Full list of author information is available at the end of the article
}

(c) 2011 Hasbun et al; licensee BioMed Central Ltd. This is an open access article distributed under the terms of the Creative Commons Attribution License (http://creativecommons.org/licenses/by/2.0), which permits unrestricted use, distribution, and reproduction in any medium, provided the original work is properly cited. 